\title{
СТАНОВЛЕНИЕ ИНСТИТУТА УПОЛНОМОЧЕННОГО ПО ПРАВАМ ЧЕЛОВЕКА В РФ И ОМБУДСМЕНА ЗА РУБЕЖОМ
}

\author{
(c) 2020 Ширёв Денис Андреевич \\ кандидат юридических наук, доцент кафедры Судебной власти, \\ правоохранительной и правозащитной деятельности Юридического института \\ Российский университет дружбы народов, Россия, Москва \\ адвокат Московского Центрального Филиала \\ Московской областной коллегии адвокатов, Россия, Москва \\ E-mail:ne205@yandex.ru \\ (c) 2020 Дёмина Елизавета Петровна \\ аспирант 2 года обучения кафедры Судебной власти, \\ правоохранительной и правозащитной деятельности Юридического института \\ Российский университет дружбы народов, Россия, Москва \\ E-mail: demina_liza2294@mail.ru
}

В данной статье рассматриваются особенности учреждения и становления отечественного института Уполномоченного по правам человека и омбудсмена за рубежом, раскрываются его роль и значение на современном этапе развития России. Путём освещения событий и правоотношений показано поэтапное становление отечественного института Уполномоченного по правам человека.

Ключевые слова: защита прав граждан, права человека, омбудсмен, Уполномоченный по правам человека, парламентский уполномоченный, Конституция, Защитник народа (Defensor del Pueblo), Haродный защитник нации (La Defensoría del Pueblo de la Nación), Meduamop (Le Défenseur des droits), Публичный защитник, Гражданский защитник, Парламентский Уполномоченный по административным расследованиям, Парламентский Уполномоченный (Омбудсмен), Публичный Советник, Общественный адвокат, Помощник граждан, коллегия народной правозащиты (Präventive menschenrechtskontrolle), комиссия по расследованиям злоупотреблений администрации, парламентская комиссия по правам человека (Parlamentārā komisija, cilvēktiesību или Tiesībsarga), Председатель Национальной комиссии по правам человека (Chairperson of National Human Rights Commission).

Развитие института Уполномоченного по правам человека имеет ряд особенностей и свою достаточно обширную историю. Изначально должность особого контролера парламента за законностью деятельности администрации была учреждена в Швеции в 1809 году и именовалась «парламентский омбудсмен».

В большинстве государств мира институт омбудсмена (в разных странах данная должность имеет своё наименование) появился существенно позднее, во второй половине XX века. Российская Федерация, перенимающая правозащитный навык Запада, приняла в свою правозащитную практику и такой институт, который был успешно апробирован, проверен временем и мировой практикой, подтвердил своё значение и колоссальную эффективность в современном мире.

В государственно-правовом смысле под термином омбудсмен определяется как «достойное доверия независимое лицо, уполномоченного парламентом на контроль в форме обширного надзора за всеми государственными должностями, но без права изменения принятых ими решений» [7]. Анализируя мнения исследователей, изучающих данную тематику, а также статьи в юридической энциклопедии можно наблюдать, что термин «омбудсмен» определяется как «специально избираемое (назначаемое) должностное лицо для контроля за соблюдением прав человека разного рода административными органами, а в некоторых странах - частными лицами и объединениями» [14].

Исходя из этого, можно предположить, что институт Уполномоченного по правам человека предполагает работу независимого лица, которое достойно уважения и доверия, осуществляет следующие направления деятельности: обеспечение гарантий государственной защиты прав и свобод человека, их соблюдения и уважения 
государственными органами, органами местного самоуправления, должностными лицами и государственными служащими, не обладая при этом правомочиями на поправки уже принятых решений.

Перед тем как анализировать ретроспективу института Уполномоченного по правам человека, необходимо сосредоточить свое внимание на то обстоятельство, что данный термин является российской разновидностью названия института омбудсмена. Существует достаточно большой спектр названий, под которыми в разных странах осуществляется деятельность омбудсменов. Так, например, в скандинавских странах, являющихся прародителями рассматриваемого института, используется название «омбудсмен юстиции», однако в тоже время, в других странах, это называется «парламентский уполномоченный».

Так, где же и для решения каких задач зародились предпосылки возникновения и становление института Уполномоченного по правам человека? Историки считают, что прародителями института Уполномоченного по правам человека являются античные государства Древняя Греция и Древний Рим, именно в них впервые была предпринята попытка взятия под контроль исполнения положений правоустанавливающих документов, касавшихся соблюдения защиты прав и свобод граждан. В Древней Греции этот орган назывался «греческая гелиэя», его основными задачами было рассмотрение жалоб на решения нижестоящих судебных органов, а также осуществление народного контроля за деятельностью должностных лиц и администраций $[18,19]$. В Древнем Риме была учреждена должность всенародных трибунов, которые не только обладали властью по вынесению возражения на заключения сената, но и могли накладывать запрет на постановления патрицианских магистратов, кроме того, они имели полномочия осуществлять задержание представленных должностных лиц [19].

В классическом варианте институт Уполномоченного по правам человека зародился в Швеции в 1809 году, имел название «специализированный парламентский омбудсмен», обладал функциями по осуществлению конституционного контроля над работой исполнительной власти, а также иных государственных органов в целях охраны прав граждан от самоуправства власти [17]. Предпосылками его зарождения послужила надобность ограничения власти короля дополнительными возможностями парламента. Так парламент наделялся правом избрания специального должностного лица, которое именовалось «парламентский комиссар». Парламентский комиссар осуществлял контроль и наблюдение за органами исполнительной и судебной власти в части соблюдения ими правовых актов, изданных парламентом [17].

Становление данного института получило своё продолжение по окончании Второй Мировой войны наряду с пониманием количества потерь и масштаба разрушений, которые принесла война, общество переосмыслило значимость и ценность соблюдения прав человека, именно поэтому институт омбудсмена был выведен на новый уровень развития. Вследствие всех предшествующих событий 10 декабря 1948 года была принята Всеобщая декларация прав человека [3], нормы, которой нашли свое отражение в национальном законодательстве многих стран, тем самым став общепринятыми нормативами прав человека.

Следующим этапом развития данного института была середина 70-х годов XX столетия и появившаяся третья волна демократизации, падения авторитарных режимов правления и перехода к демократии. Данные события повысили роль института омбудсмена в перечне структур государственной власти, в том числе и потому, что отказ от обслуживания интересов правящей элиты направил его деятельность на благо большинства населения [6].

Омбудсмен являлся не только важным институтом вневедомственного государственного контроля, он также участвовал в решении проблемных вопросов обычных людей. В конце концов, он и сам был в основной массе чистой формой «власти авторитета», так как не являлся «властью силы». Само его наличие в организации императивных институтов указывало и указывает о развитии государственного аппарата. Не спроста в пост-франкистской Испании институт омбудсмена приобрел наименование «Защитник народа» (Defensor del Pueblo - Испания) - является Верховным комиссаром генеральных судов, который отвечает за защиту основных прав и общественных свобод граждан путём контроля за деятельностью испанских государственных органов. Данная должность (Defensor del Pueblo) была учреждена 6 апреля 1981 года, тогда парламент одобрил органиче- 
ский закон 3/1981, а сам закон был опубликован в официальном государственном вестнике 7 мая. [22]. Любой гражданин может обратиться к омбудсмену с просьбой о его вмешательстве, для расследований любых действий (предположительно неправомерных) испанской государственной администрации или ее агентов. Он, также может, по своей собственной инициативе, вмешиваться в дела, которые ему известны, даже если по ним не было подано никаких жалоб. В дальнейшем, данный институт, стремительно распространилось на всю Латинскую Америку [17]. В частности, в Аргентине, данный институт именуется «Народный защитник нации» или Управление народного защитника нации (La Defensoría del Pueblo de la Nación). Народный защитник нации - институт, действующий с полной независимостью и функциональной автономией, задачей которого является защита гражданских прав, гарантий и интересов, закрепленных в национальной Конституции и законах, от действий, или бездействия администрации и контроля за осуществлением государственных административных функций. Народный защитник нации избирается Национальным Конгрессом, и его компетенция закреплена в статьях 43 и 86 национальной Конституции и закона № 24.284 с поправками, внесенными Законом № 24.379 [23]. В Боливии «Защитник народа» (La Defensoría del Pueblo) создан в 1994 году в соответствии с Конституцией и призван обеспечивать осуществление, поощрение, распространение и соблюдение индивидуальных и коллективных прав человека, закрепленных в Конституции, законах и международных документах. Он также несет ответственность за обеспечение защиты прав коренных народов, проживающих в сельской местности, городских и межкультурных общин, а также боливийцев за рубежом [24].

Более подробно стоит сказать об институте омбудсмена во Франции. Это обусловлено высоким уровнем успешности деятельности омбудсменов или как во Франции принято называть «медиаторов» [6].

Так, проблемы, на которых заостряет свое внимание институт омбудсмена во Франции были следующие: 1. Проблема эффективной защиты прав и свобод гражданина перед лицом государства и его аппарата; 2. Проблема расширения и укрепления демократических институтов, свойственных развитому гражданскому обществу; 3. Проблема оптимального использо- вания права и правового инструментария в целях достижения наивысшего уровня народного благосостояния [6].

Необходимо отметить, возникновение института омбудсмена в государствах с разными формами правления демонстрирует формирование настоящих демократических основ и ценностей, а также возводит права и свободы человека и гражданина в приоритетное положение при исполнении государственными органами и их должностными лицами властных предписаний.

На уровне Европейского Союза после заключения Маастрихтского договора (The Treaty of Maastricht) в 1992 г. была учреждена должность Европейского медиатора, введенная в действие в 1995 г. [11]. Этот «региональный» медиатор назначается на должность (сроком на 5 лет) посредством участия в элективной процедуре, проводимой Европейским парламентом. Полномочия Европейского медиатора, состоят в исполнении надзора за работой организаций Европейского сообщества в сфере соблюдения прав и законных интересов человека и гражданина. Одним из главных полномочий является рассмотрение жалоб граждан на органы администрации [21].

В универсальных организациях также предусмотрена должность омбудсмена. В Организации Объединенных Наций, омбудсмен содействует в решении возникающих спорных ситуаций и конфликтов, но при этом всегда придерживается нейтральной стороны. Омбудсмен не выступает в роли представителя или защитника, какой-либо стороны спора, так как, согласно мнению ученых, которые освещают данную проблематику, его деятельность «содействует выработке общего решения, удовлетворяющего условия обеих сторон, что в свою очередь ближе к функционалу медиатора» [12].

Независимость омбудсмена ООН является принципиальным условием, иначе невозможно оставаться нейтральными и беспристрастным оказывая непосредственное содействие в разрешении сложившейся конфликтной ситуации. Ещё одним из важных условий является соблюдение принципа конфиденциальности. При реализации своих полномочий омбудсмен ООН не подотчетен каким-либо органам ООН или сторонам конфликта. При этом немаловажно отметить, что омбудсмен ООН не обладает полномочиями по участию в официальных судебных или административных действиях, которые могут 
затрагивать те проблемы, в разрешении которых он оказывал содействие [12].

Согласно мнению Помощника Генерального секретаря Службы омбудсмена и посредничества ООН Джонстона Барката: «омбудсмен старается найти наиболее основательные обстоятельства затруднений и посоветовать, что необходимо изменить для того, чтобы в будущем свести их к минимальному количеству и сформировать в Организации Объединенных Наций наиболее подходящую рабочую обстановку» [15].

В отличие от опыта зарубежных государств, учреждение института омбудсмена в России произошло значительно позже, а точнее, осенью 1990 года, сначала в виде предложения по включению в разработку новой Конституции РСФСР [4] статьи, закрепляющей должность Государственного комиссара Верховного Совета по правам человека и регламентирующей его деятельность. Первое упоминание о закрепленном де-юре термине «институт Уполномоченного по правам человека» можно встретить в статье 40 Декларации прав и свобод человека и гражданина, которая принята Постановлением ВС РСФСР от 22.11.1991 года [5]. Данная статья предусмотрела формирование Парламентского уполномоченного по правам человека. Правовой статус этого должностного лица предполагал наличие неприкосновенности, аналогичной той, что и у народного депутата РСФСР. Постановлением устанавливался пятилетний срок исполнения полномочий. Идея авторов Декларации заключалась в том, что функционал Парламентского уполномоченного по правам человека и порядок их реализации обретут нормативную фиксацию в отечественном законодательстве, поскольку проекты законодательных актов подготавливались соответствующим комитетом Верховного Совета, однако, эти планы так и не были реализованы [8].

В период с 1992-1993 г. происходит усиление конфронтации между исполнительной и законодательной ветвями власти, приводящей к тому, что в Конституции, проект которой обсуждался с мая 1993 года и был принят по итогам плебисцита 12 декабря 1993 года [1], сохранилась только одна норма, которая затронула вопрос об Уполномоченном по правам человека, а именно ст. 103, согласно которой Государственная Дума Федерального Собрания Российской Федерации наделялась правом рассмотрения кандидатуры претендента на должность Уполномоченного по правам человека, а также при наличии поводов и оснований принятия решения об освобождении от неё. При этом полномочия и функционал Уполномоченного по правам человека должны регламентироваться нормами федерального конституционного закона, который на тот момент ещё не был принят.

До принятия федерального конституционного закона работа института Уполномоченного по правам человека регламентировалась Указом Президента Российской Федерации от 04.08.1994 № 1587 «О мерах по обеспечению конституционных функций Уполномоченного по правам человека» [2]. В соответствии с Указом до принятия соответствующего федерального конституционного закона реализация конституционных функций Уполномоченного по правам человека обеспечивается путем осуществления им полномочий, данных председателю Комиссии по правам человека при Президенте Российской Федерации. Кроме того, Указом была зафиксирована обязанность должностных лиц по предоставлению информации, необходимой для реализации Уполномоченным по правам человека своих полномочий, что можно было рассматривать как гарантию в обеспечении его деятельности [2].

Первым Уполномоченным по правам человека в Российской Федерации 17 января 1994 года стал правозащитник С.А. Ковалев. Поскольку с сентября 1993 года Ковалёв находился на посту председателя Комиссии по правам человека при Президенте Российской Федерации, можно смело утверждать о его более раннем назначении в качестве первого российского омбудсмена [20].

На данном этапе в мире институт Уполномоченного по правам человека является неким «правовым мостом» между пострадавшими гражданами и государством или должностными лицами. Поскольку деятельность омбудсмена заключается не только в рассмотрении жалоб и заявлений граждан, но и самостоятельно, при получении информации о нарушении прав граждан, принятии соответствующих мер.

В тот же момент даже несмотря на то, что деятельность омбудсмена носит не обязательный, а рекомендательный характер, его рекомендации чаще всего бывают исполнены. Всё это происходит потому, что в государстве данный институт имеет определённый авторитет.

Так, одним из главных рычагов для повы- 
шения уровня престижа данного института является общественное мнение и демонстрация его работы. Непосредственно по этой причине, в случае если омбудсмен не был доволен реакцией на свои рекомендации, он обладает право прибегнуть к средствам массовой информации для создания общественного резонанса.

Рассуждая о становлении Уполномоченного по правам человека в системе органов государственной власти, можно прийти к следующим выводам:

1. Омбудсмен, как и Уполномоченный по правам человека должен обладать обширными знаниями в области права и иметь высокие профессиональные навыки, а также иметь всеобщее признание.

2. У Уполномоченного по правам человека существует своё особенное правовое положение, которое заключается в том, что он де-юре не принадлежит ни к одной из ветвей власти, что, в свою очередь, позволяет рассуждать о его своеобразном месте в государственно-правовой структуре общества.

3. Характерным фактором развития института омбудсмена за рубежом особенно на первоначальных этапах, является реализация омбудсменом функции, которые были направленны на повышение эффективности деятельности чиновников исполнительной власти (по сути результаты их деятельности отражали реальную картину соблюдения прав человека в социально направленном государстве) [9]. О приоритетном значении этой функции свидетельствует название омбудсмена в англосаксонских странах Уполномоченный по делам администрации.

4. В большинстве стран институт омбудсмена (публичного защитника, и т.д.) возник существенно позже, во второй половине XX столетия. Отчизна, перенимая правозащитный навык Запада, одолжила и данный правозащитный институт, который был проверен мировой практикой, со временем подтвердивший свою значительную ценность и огромную результативность.

В разных государствах должность омбудсмена называется по-разному. Таким образом, во Франции это Медиатор (Le Défenseur des droits) - он отвечает на 5 основных задач: 1 . Защита прав и свобод в отношениях с органами государственной власти, территориальными органами, государственными учреждениями и органами государственной службы; 2. Защищать и содействовать в защите интересов и прав ребен- ка, закрепленных в законе или международных нормативных актах, регулярно ратифицированные или утвержденные Францией; 3. Борьба с дискриминацией и содействие равенству, прямо или косвенно запрещенной законом или международными нормативными актами, регулярно ратифицированными или утвержденными Францией; 4. Обеспечение соблюдения этических норм лицами, которые осуществляют деятельность по обеспечению безопасности на территории Республики Франции; 5. Обратиться к властям по смыслу закону от 9 декабря 2016 г. и обеспечить права и свободы человека [26]. В провинции Квебек (Канада) - Публичный защитник (Public defender), в Италии - Гражданский защитник (Il Difensore civico): в первую очередь следует отметить то, что омбудсмен не является судьей, который выносит решения или накладывает штрафы. Он никогда не может вмешиваться в споры между частными лицами, вмешиваться в вопросы, связанные с общественными отношениями о занятости. Приоритетной задачей является устранение дискриминации, злоупотребление положением должностных лиц, устранением споров между гражданином и государством, т.е. он пытается, в убедительной форме и пользуясь своим авторитетным положением, устранить конфликты и защитить права и свободы лица. Именно поэтому он имеет право вмешиваться в конкретные дела, в том числе запрашивать информацию о состоянии документов и дела, может указывать правоохранительным органам принимать меры для устранения возникших ситуаций [16].

В некоторых государствах функционал омбудсмена возлагается на коллективные органы:

- Коллегия народной правозащиты (Präventive menschenrechtskontrolle - Австрия) омбудсмен отвечает за защиту и продвижение прав человека в Австрийской Республике с 1 июля 2012 года. Вместе с шестью региональными коллегиями проверяют объекты, в которых происходят или же могут происходить лишение или ограничение личной свободы (Например: в тюрьмах или домах престарелых). Также контроль распространяется на средства и программы для людей с ограниченными возможностями. Кроме того, коллегии относится исполнительной властью, если применяется прямое принуждение (Например: в случае депортации, операций полиции и демонстраций). Основная задача - выявление и устранение факторов ри- 
ска нарушений прав человека на ранней стадии [25].

- Комиссия по расследованиям злоупотреблений администрации (National Human Rights Commission - Непал),

- Парламентская комиссия по правам человека (Parlamentārā komisija, cilvēktiesību или Tiesībsarga - Латвия) общество наделило омбудсмена защищать права человека, предотвращать дискриминацию и содействовать законному и эффективному разрешению конфликтов с публичной властью в соответствии с законом. Омбудсмен, также наделен правом обнаруживать неточности в правовых актах и их применению, а также содействовать устранению данных ошибок. Способствовать к информированию и просвещению по вопросам защиты прав человека, создание механизмов защиты прав человека и работы омбудсмена [16].

5. Пост Уполномоченного по правам человека в Российской Федерации был учреждён для обеспечения гарантий охраны гражданских прав и свобод, их соблюдения и уважения государственными органами, органами местного самоуправления, должностными лицами и государственными служащими [10]. Функционирование института Уполномоченного расширяет имеющиеся ресурсы охраны прав и свобод граждан. При этом результаты его деятельности не отменяют и не влекут пересмотра компетенций государственных органов, которые обеспечивают охрану, защиту от посягательств и восстановление нарушенных прав и свобод. Учреждение института Уполномоченного по правам человека в субъектах РФ является исключительной прерогативой последних [13].

\section{Библиографический список}

1. «Конституция Российской Федерации» (принята всенародным голосованием 12.12.1993) (с учетом поправок, внесенных Законами РФ о поправках к Конституции РФ от 30.12.2008 № 6-ФКЗ, от 30.12.2008 № 7-ФКЗ, от 05.02.2014 № 2-ФКЗ, от 21.07.2014 № 11-ФК3).

2. Указ Президента Российской Федерации от 04.08.1994 № 1587 «О мерах по обеспечению конституционных функций Уполномоченного по правам человека».

3. «Всеобщая декларация прав человека» (принята Генеральной Ассамблеей ООН 10.12.1948).

4. Закон РСФСР от 15.12.1990 № 423-1 «Об изменениях и дополнениях Конституции (Основного Закона) РСФСР».

5. Постановление ВС РСФСР от 22.11.1991 № 1920-1 «О Декларации прав и свобод человека и гражданина».

6. Бойцов B. В. Служба защиты прав человека и гражданина. Мировой опыт. М.: Норма, 2006.

7. Бойцова В.В. Служба защиты прав человека и гражданина: мировой опыт [Текст]/ В. В. Бойцова.-М.,1996.

8. Бойцова Л. В. Настоящее и будущее российского омбудсмена [Текст] / Л. В. Бойцова, В. В. Бойцова // Юридический мир: ежемесячный общеправовой журнал -2003.-№ 3.

9. Государственная политика и управление: учебник: в 2 ч. / Л.В.Сморгунов, А.П.Альгин, И.Н.Барыгин [и др.]; под ред. Л. В. Сморгунова., ч. 1: Концепции и проблемы государственной политики и управления.М.: РОССПЭН, 2006, с.184.

10. Маслов Е. Значение института омбудсмена в России // Вестник Уполномоченного по правам человека в Московской области. М., 2001. № 1. с. 12.

11. Мешкова А.В. Становление и развитие института Омбудсмена в зарубежных странах. Электронный журнал «Вестник МГОУ» / www.evestnik-mgou.ru. - 2014. - № 2 [Электронный ресурс] - Режим доступа: https:// evestnik-mgou.ru/ru/Articles/Doc/553 (дата обращения: 19.03.2020).

12. Принципы, которыми омбудсмен руководствуется в своей работе - Омбудсмен ООН и посреднические услуги [Электронный ресурс] - Режим доступа: http://www.un.org/ru/ombudsman/principles.shtml (дата обращения: 20.04.2020).

13. Региональный омбудсмен. / Под редакцией А.Ю.Сунгурова. Приложение к журналу «Северная Пальмиpa».-СПб., 1999.-226 с., С. 147.

14. Российская юридическая энциклопедия [Текст].-М., 2000.

15. Сморгунов Л.В., Альгин А. П., Барыгин И. Н. (и др.); под ред. Сморгунова Л. В., Государственная политика и управление: учебник: в 2 ч. / ч. 1: Концепции и проблемы государственной политики и управления.- М.: РОССПЭН, 2006, с.184.

16. Сунгуров А.Ю. Сравнительный анализ института омбудсмена//Развитие института Уполномоченного по правам человека в российских регионах. Т. 2: Региональный омбудсмен/под ред А. Ю. Сунгурова. Приложение к журналу «Северная Пальмира». -СПб., 1999. 
17. Хиль-Роблес А. Парламентский контроль над администрацией (институт омбудсмена). М.: Московская школа политических исследований, 2004. 360 с.

18. Большой юридический словарь.- М.: Инфра-М. А. Я. Сухарев, В.Е. Крутских, А. Я. Сухарева. 2003

19. Хрестоматия по истории государства и права зарубежных стран: учеб. пособие: в 2 т. / под ред. К. И. Батыра и Е.В.Поликарповой. М.: Проспект, 2014. Т.1. 392 с.

20. Цымбалова Н.А. История учреждения института омбудсмена в России // Комиссии и уполномоченные по правам человека: опыт российских регионов. -СПб.: Норма,-2002. с. 105-114.

21. The European Ombudsman - Origins, Establishment, Evolution - Commemorative volume published on the occasion of the 10th anniversary of the institution [Электронный ресурс] - Режим доступа: http://www. ombudsman.europa.eu/resources/historicaldocuments. faces (дата обращения: 20.04.2020).

22. Официальный сайт «Защитник народа» (Defensor del Pueblo - Испания) [Электронный ресурс] - Режим доступа: https://www.defensordelpueblo.es/el-defensor/historia-del-defensor/ (дата обращения: 01.07.2020 г.)

23. Официальный сайт Народного защитника нации или Управление народного защитника нации в Аргентине (La Defensoría del Pueblo de la Nación) [Электронный ресурс] - Режим доступа: http: //www.dpn.gob.ar/ dpn.php (дата обращения: 01.07.2020 г.)

24. Официальный сайт Народного защитника Боливии (La Defensoría del Pueblo) [Электронный ресурс] - Peжим доступа: https://www.defensoria.gob.bo/contenido/sobre-nosotros (дата обращения: 02.07.2020 г.)

25. Официальный сайт Коллегии народной правозащиты Австрии (Präventive menschenrechtskontrolle) [Электронный ресурс] - Режим доступа: https://volksanwaltschaft.gv.at/praeventive-menschenrechtskontrolle (дата обращения: 01.07.2020 г.)

26. Официальный сайт Медиатора Франции (Le Défenseur des droits) [Электронный ресурс] - Режим доступа: https://nationale/les-institutions-francaises-generalites/le-defenseur-des-droits (дата обращения: 01.07.2020 г.) 